\title{
OBITUARY
}

\section{URSULA KATHERINE DUNCAN}

17 September 1910-27 January 1985

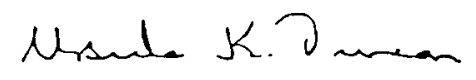

Ursula Duncan MA, LLD, FLS, LRAM, was born in Kensington, London, in 1910, the elder daughter of Commander J. A. Duncan and his wife, the former Dorothy Weston. During her infancy, the Duncan family, whose origins in Angus can be traced back to 1705, returned to Parkhill, Arbroath, their ancestral home since 1799. Dr Duncan's childhood education was entrusted to a governess, Miss Isobel Leslie, and under her tutelage she passed the Entrance School Certificate to Cambridge at the age of 15, obtaining a distinction in Greek. Of studious and intellectual bent, Dr Duncan registered as an external student of London University obtaining a BA in 1952 and a MA in 1956 in classics, a period during which she also visited Greece. She also became a pianist of some distinction, excelling in musical theory and professing a preference for Bach and Mozart; she obtained a Licentiate of the Royal Academy of Music.

During World War II she served for a time in the Censorship Department, based on Inverness, dealing with the censorship of forces mail, an experience which she confided 'brought her face to face for the first time with harsher realities of personal life' and from which she derived an understanding and experience of people which she valued in later life. The death of her father in 1943 curtailed her work in Inverness, and she returned to Parkhill to take over the supervision of the family estate, including 600 acres of farmlands, an undertaking which she proceeded to carry out with financial astuteness, foresight and considerable success for the rest of her life.

Her interest in botany commenced at the age of ten, and she was much encouraged in the pursuit by her father after his retirement from the Royal Navy at the end of the World War I. What was destined to be her major recreation throughout life started with vascular plants and extended in 1939 to the bryophytes and hepatics as well as the lichens.

She was a member of the Wild Flower Society from her youth and joined the Botanical Society of the British Isles in 1931, becoming the recorder for Easter Ross and serving on the Committee for the study of the Scottish Flora for many years. As with her studies of cryptogams, she delighted in those genera which presented a taxonomic challenge, such as Potamogeton, Hieracium and Taraxacum; she always considered the grasses as the most intractable and she became a considerable expert in this group. With these 'little difficulties' she kept up a life-long correspondence with a wide range of specialists who, in turn, benefitted greatly from her many new records, collections and valuable field 
data, mostly from botanically under-explored areas of Scotland. Her personal generosity and kindness to her botanical friends, young or old, amateur or professional, became one of the hallmarks of her considerable botanical flair and her great succes as a field botanist.

The publication of the Flora of East Ross-shire in 1980 marked the successful culmination of many years of intrepid and tireless tramping to all areas of the vice county, often alone, in inhospitable terrain, and in all types of weather, always, characteristically, in wellington boots! She also had a particular interest in the floras of Angus and the Island of Mull; indeed her preliminary studies on the vegetation of Mull were largely instrumental in the initiation of the Flora of Mull Project carried out by the Botany Department, British Museum (Natural History), to which she subsequently gave generous and wholehearted support.

She was introduced to lichenology by $\mathrm{Mr} \mathrm{R}$. H. Burn of Oxford and $\mathrm{Dr} W$. Watson of Taunton and soon became one of the select few who kept lichenology alive during the period of its greatest decline in Britain between 1945 and 1955. Even more importantly, by unstintingly putting her time, knowledge and collections at the service of young aspiring lichenologists she undoubtedly played a premier rôle in the renaissance of the subject in Britain. Those of us privileged to attend her courses at Kindrogan Field Centre or come under her guidance at British Lichen Society field meetings have treasured memories of the great enjoyment, humour and value of those occasions. Of her three books on lichens, the last, An Introduction to British Lichens, published in 1970 , reflects the resurgence of interest in the group and the major part she played in its revival. She was a founder member of the British Lichen Society. As with other groups of plants, she contributed records continually to mapping schemes and census catalogues, providing, for instance, over $25^{\circ}$ " of the Scottish records in Watson's Census Catalogue of British Lichens (1953).

Her early studies on bryophytes and hepatics were with her namesake $\mathrm{Mr}$ J. B. Duncan, and she soon became an active member of the British Bryological Society. It was characteristic that her interest turned in particular to the challenge offered by the Sphagnales, for which she acted as a referee and published an illustrated key. As with vascular plants and lichens, she also acted as a referee for beginners, ecology students, mapping recorders, etc., attending to their many letters and specimens with prompt and meticulous thoroughness.

She eschewed formal representation on committees and was happiest when in the field, either gently and patiently encouraging 'her beginners in smalls and greens' or, with botanical friends, amateur or professional, exchanging specimens and expertise, or leading one of the many field meetings to many parts of the British Isles. She had a rare intuitive flair which made her an outstanding field botanist in addition to being a naturally gifted teacher with an instinctive ability for conveying her enthusiasm and knowledge whatever the level of experience of the recipient. Reticent about her many achievements and naturally modest by nature, she never sought the limelight and was most content in the surroundings of her own home. Friends who visited her were always welcome and were able to share with her enthusiasm for gardening, particularly her interest in vegetable growing, rhododendrons, Meconopsis, Cardiocrinum and, in the quarry which furnished the building stone for Parkhill, a fine range of Primula species. 
She amassed a large and important herbarium of vascular plants, rich in carefully collected material of critical and difficult taxa and much of it identified or checked by specialists; she donated this to Dundee Museum in 1983. Failing eyesight and ill-health caused her to give her cryptogams to the herbarium of the Royal Botanic Garden, Edinburgh later in that year. The lichens in her collection contained several first records for Britain, innumerable new vice county records, and much critical material.

Dr Duncan was honoured by the Linnean Society with the H. H. Bloomer Award, the British Lichen Society by an honorary membership and, in 1969, by the University of Dundee with the honorary degree of Doctor of Laws, public recognition and expressions of gratitude for her private generosity and kindness to all whom she helped and who shared her enthusiasm for plants and their habitats, as well as recognition of her unique contribution to British botany; her humanity and philanthropism will be much missed and serve as an example to us all.

P. W. James *

^Department of Botany, British Museum (Natural History), Cromwell Road, London SW7 5BD, LK. 
